\title{
PERCEPTIONS, KNOWLEDGE, AND ATTITUDES OF STUDENTS TOWARDS SAFETY PRACTICE IN CULINARY LABORATORIES
}

\author{
Ismail, M. E., Harun, H., Abdul Razzaq, A.R., Irwan Mahazir, I., Abd Samad, N., Othman, H. \\ Faculty of Technical and Vocational Education, Universiti Tun Hussein Onn Malaysia \\ E-mail: erfy@uthm.edu.my
}

\begin{abstract}
The variety of tools and equipment requires a modern and sophisticated safety management for practical works in a laboratory. It is susceptible to the risk of an accident if safety is ignored. Therefore, this study conducted a descriptive survey to assess perceptions, knowledge, and attitudes of students in the course of culinary about safety practices in culinary laboratories. The population consisted of 90 students from the first year until the fourth year, which comprises the entire study population involved in practical works in the laboratory. Nonrandom sampling using a purposive sampling technique used as the sampling method and involved 60 samples. The instruments were a questionnaire to obtain information. Data were collected and analyzed statistically. Based on the pilot study analysis, the reliability of the instrument was 0.91 categorized as high. Results showed that good safety practices give positive influence on knowledge, attitudes, and perceptions of students towards safety practice in culinary laboratories. The study showed that a safe and orderly work culture is capable of creating disciplined and responsible attitudes.
\end{abstract}

Keywords: attitude, culinary perception, knowledge, safety practice, technical and vocational education

\section{INTRODUCTION}

In increasingly and rapidly build technological development, a country must have skilled workers and are aware of the use of equipment and more modern machines. Thus, students at the time of the present generation have a very important role in the realization of these increasingly sophisticated technologies. Jalil (2014) states that based on Malaysia's Transformation Program of Vocational Education, the academic system in schools will be reduced and will be changed and the addition of industry practice or practical for technical students will be implemented to create a skilled and knowledgeable individual that can produce high quality and efficient workers. Therefore, Technical and Vocational Education (TVE) is the field of education under the administration of the Ministry of Education to provide extensive opportunities for students to develop their potential and talent. With this, it can be seen, most of the learning and teaching of TVE in secondary technical schools or vocational colleges, the majority of study learning and teaching practical or practical skills during the process is carried out in class or laboratory.
Technical and Vocational Education offers programs that enable them to participate in a variety of technical and vocational fields such as culinary. In addition, the field of electrical and electronics, welding, automotive, business services are offered. Alavi \& Sail (2015) explain that most students choose to pursue studies in technical and vocational fields, especially in the field of hospitality, better known as culinary. The hospitality industry is one field that allows students to become semi-professional potential and enable them to market themselves in the employment sector. This is because in this course, it is more focused on learning through practical methods.

Learning through practical methods, also known as hands-on will accelerate the learning process that takes place because the students themselves who will conduct an investigation to obtain information through the actual material (Winberg \& Berg, 2007). With this, it can be seen, most of the learning and teaching of TVE in secondary technical schools or vocational colleges, the majority of study learning and teaching practical or practical skills during the process are carried out in classes or laboratories. The process of learning 
through practical methods carried out by the students will make them vulnerable to accidents and personal safety while studying and doing practical work process (Flin et al., 2008; Hidayat \& Wahyuni, 2016). Based on the report from Malaysia's Department of Occupational Safety and Health (2016), parts of accidents that occur as a permanent disability that often occurs in the laboratory.

Tran \& Nyland (2013) stated that safety in the culinary field should be considered especially when undergoing practical work in the laboratory. Accidents which are common in the laboratory can be avoided if students continue to adopt and comply with the safety measures that have been provided (Jaafar et al., 2015). Therefore, to train and develop the necessary manpower towards industrialized countries, the students need to be trained in order to have the right attitude and diligence to work (Yusof, 2014). According to Negara (2012), workplace safety is an aspect that should be the main focus in doing practical work while in the laboratory. It should be emphasized not only while doing practical work even it at any time when students are in the laboratory. Therefore, the students should always be aware of personal safety at any time and any place of studies because of an accident or disaster regardless of time and place. In addition, students also have to adopt a clear stance before touched and keep safety in laboratories.

Teaching and learning through practical methods in the culinary laboratory, it's more focused on the use of laboratories and compared to the use of classrooms (Malamud \& Pop-Eleches, 2010). Ismail \& Talip (2010), states that a laboratory is a place with a variety of equipment that requires skills and knowledge of students and lecturers in using surveillance equipment to avoid unwanted accidents and launch a process of teaching and learning that takes place.

Aziz et al. (2015) define an accident as an unexpected and unintended effect that can result in physical injury to people, damage to property, incidents, and losses. In addition, accidents can happen due to the layout or laboratory management. This statement is supported by Ishak (2013), who said the accident may occur as a result of failure layout management in laboratories. Bakar \& Zulpakar (2008) add that accidents involving the use of the equipment will take place if it is not kept and maintained properly from time to time. Furthermore, the preparation of the items and the surrounding space in the garage culinary laboratory can cause accidents as a small laboratory space and composition of students can cause accidents (Mills et al., 2009). Every individual should not pose a danger and cause damage to the tool and the machine.

Cullen (2010) emphasizes that an individual should understand and practice the safety in the laboratory by adopting the concept before, during and after using the equipment in the laboratory. Yusof (2014) explains that safety practices are important when doing the work by sensitizing students to practice and adhere to the safety measures provided. Most students entering the vocational and technical laboratories, they do not have the initial setup and tidy before doing practices in their learning process. They are confident in the safety aspects during the laboratory under the supervision of a teacher or technician, causing the student to complete careless and negligent themselves. Boon \& Kamarudin (2010) and Ahmad (2015), explain that the level of preparedness in terms of knowledge of safety practices while doing practical work in the laboratory is located at the medium level. Thus, the knowledge, attitude, and awareness of safety practices are crucial in ensuring safety is assured during practical work in progress.

Ozilgen (2011) indicates that the accident is a major contributor to students who are not have disciplined in a laboratory. The attitude of selfishness in practical works in the culinary laboratory make minor accidents and minor injuries. Mahmood \& Zakaria (2007) argue that the attitude of students who do not take care the aspects of safety interests would 
be exposed to the risk of an accident. Negara (2012) suggested that students need to be trained by the instructors at the school in order to have the right attitude to work and have positive values such as discipline, patience, and dedication in order for them to safely practice in the laboratory so that accidents can be avoided.

In addition, Ahmad (2015) states that students who have a positive perception of themselves on the facilities at the school, they will affect the performance of other students. This is because the perception of students on a matter like safety will give a positive outlook that could reflect the impact of better safety practices in a laboratory atmosphere and if the perception of the situation otherwise it can give a negative impact on safety practices in the laboratory. Thus, in the effort to reduce this problem, the study on perceptions, knowledge, and attitudes towards practice and safety in laboratories was conducted, to prevent the occurrence of accidents and creating a work environment that is comfortable and safe for culinary students.

\section{METHOD}

The research methodology is determined by the design of the study through a survey. It used the method of quantitative research using questionnaires as the instrument to get the data and information for answering the research questions. Piaw (2014) suggests that the survey is comprehensive in nature, which may comment on the issue from various points of views, how easy handling can accumulate and collect data quickly, corresponding to the large sample size, the information obtained directly and able to make decisions collectively. The population in this study were 90 respondents consisting of male and female students from the first year until the fourth year students in the culinary courses at Muar Vocational College, which comprises the entire study population involved in doing practical works in the culinary laboratory. The sample used is not random sampling. The sampling aimed where researchers choose a sample in order to obtain 60 samples of the total population (Konting, 2009). Besides, in this study, the validity was made to ensure the questionnaire can be used. Content validity was used in this study. Moreover, the pilot study was carried out to obtain the reliability of the questionnaire. Based on the analysis that has been made, Alpha Cronbach value was 0.92 categorized as a high level.

The real data obtained from the questionnaires were collected and analyzed descriptively. The mean score analysis was presented in Table 1. All parts contained in this questionnaire were analysed by assessing the mean score for each item based on a four points Likert scale adapted from Osman et al. (2012).

Table 1. Mean Score Analysis

\begin{tabular}{cc}
\hline Mean score & Level \\
\hline 1.00 to 2.00 & Low \\
2.01 to 3.00 & Moderate \\
3.01 to 4.00 & High \\
\hline
\end{tabular}

\section{RESULTS AND DISCUSSION}

Table 2 shows the results of the respondents involved in the questionnaire.

Table 2. Mean and Standard Deviation of Students' Perception towards Safety Practices in the Culinary Laboratory

\begin{tabular}{lcc}
\hline No & \multicolumn{1}{c}{ Items } & $\begin{array}{c}\text { Mean } \\
\begin{array}{c}\text { Standard } \\
\text { deviation }\end{array}\end{array}$ \\
\hline A1 Safety practice in the laboratory was able to contribute positively to students' daily lives. & 3.49 & 0.66 \\
A2 Safety can be fostered through safety practices that apply to students. & 3.47 & 0.6 \\
A3 Safety practices are applied through practical classes in the laboratory can be forwarded up & 3.53 & 0.58 \\
to the real job. & 3.42 & 0.53 \\
A4 The main causes of accidents in the laboratory are human negligence. & 3.34 & 0.69 \\
A5 The overconfident attitude among students while doing practical work can pose a danger to & & \\
$\quad$ others. & 3.44 & 0.67 \\
A6 Laboratory safety rules is an important matter that must be known by every student. &
\end{tabular}


According to the item obtained, the mean result is at a high level and shows the respondents strongly agree with the given item. The respondents agreed that the safety practice in the practical classes will be carry forward for the real job environment. Table 3 shows the results of the respondents involved in the questionnaire. According to the item obtained, the mean result is at a high level and shows the respondents strongly agree with the given item. The respondents agreed that the use of equipment and the importance of putting equipment in the appropriate place.

Table 3. Mean and Standard Deviation of Students' Knowledge towards Safety Practices in the Culinary Laboratory

\begin{tabular}{|c|c|c|c|}
\hline Number & Items & Mean & $\begin{array}{r}\text { Standard } \\
\text { deviation }\end{array}$ \\
\hline B1 & $\begin{array}{l}\text { I always start } \\
\text { practical work in } \\
\text { the culinary } \\
\text { laboratory } \\
\text { without } \\
\text { lecturer's } \\
\text { instructions. }\end{array}$ & 2.23 & 1.02 \\
\hline B2 & $\begin{array}{l}\text { I understand the } \\
\text { method of using } \\
\text { equipment } \\
\text { properly }\end{array}$ & 3.4 & 0.65 \\
\hline B3 & $\begin{array}{l}\text { I understand that } \\
\text { the equipment } \\
\text { should be kept in } \\
\text { designated } \\
\text { places in the } \\
\text { culinary } \\
\text { laboratory. }\end{array}$ & 3.5 & 0.64 \\
\hline B4 & $\begin{array}{l}\text { I emphasize } \\
\text { personal safety } \\
\text { while in the } \\
\text { culinary } \\
\text { laboratory. }\end{array}$ & 3.4 & 0.71 \\
\hline B5 & $\begin{array}{l}\text { I know that the } \\
\text { use of jewellery } \\
\text { is prohibited } \\
\text { while doing } \\
\text { practical works. }\end{array}$ & 3.42 & 0.76 \\
\hline B6 & $\begin{array}{l}\text { I have } \\
\text { knowledge of } \\
\text { laboratory safety } \\
\text { before entering } \\
\text { the culinary } \\
\text { laboratory. }\end{array}$ & 3.32 & 0.71 \\
\hline
\end{tabular}

Table 4 shows the results of the respondents involved in the questionnaire according to the item obtained the mean result is at a high level and shows the respondents strongly agree with the given item. The respondents agreed that the students make sure the equipment is in good condition before it is used.

Table 4. Mean and Standard Deviation of the Attitude toward Safety Practices In the Culinary Laboratory.

\begin{tabular}{|c|c|c|c|}
\hline Number & Items & Mean & $\begin{array}{l}\text { Standard } \\
\text { deviation }\end{array}$ \\
\hline C1 & $\begin{array}{l}\text { I always clean } \\
\text { the equipment } \\
\text { used after the } \\
\text { completion of } \\
\text { work on } \\
\text { practical work. }\end{array}$ & 3.33 & 0.75 \\
\hline $\mathrm{C} 2$ & $\begin{array}{l}\text { I will make sure } \\
\text { the equipment is } \\
\text { in good } \\
\text { condition before } \\
\text { to prevail so safe } \\
\text { to use. }\end{array}$ & 3.51 & 0.64 \\
\hline C3 & $\begin{array}{l}\text { I adhere to the } \\
\text { regulations set } \\
\text { all the time } \\
\text { while in the } \\
\text { culinary } \\
\text { laboratory. }\end{array}$ & 3.33 & 0.71 \\
\hline $\mathrm{C} 4$ & $\begin{array}{l}\text { I always use the } \\
\text { laboratory } \\
\text { equipment in the } \\
\text { right way. }\end{array}$ & 3.37 & 0.71 \\
\hline $\mathrm{C} 5$ & $\begin{array}{l}\text { I will get } \\
\text { permission from } \\
\text { the lecturer } \\
\text { before using the } \\
\text { laboratory } \\
\text { equipment. }\end{array}$ & 3.49 & 0.65 \\
\hline C6 & $\begin{array}{l}\text { I will ensure that } \\
\text { the laboratory is } \\
\text { always clean } \\
\text { before being } \\
\text { abandoned. }\end{array}$ & 3.42 & 0.65 \\
\hline
\end{tabular}

Personal safety while in the culinary laboratory is emphasized in order to avoid an accident. Accidents can be avoided if a student is practicing personal safety, equipment, and culinary laboratory. This statement is supported 
by Bahari (2006), who said that the implemented safety practices can prevent the occurrence of an accident, injury, or damage during the internship process is carried out. Based on the analysis carried out to see how students' perceptions of safety issues and the safety practices in the culinary laboratory, it was assessed by the context of consumer safety practices in one's life.

Results showed that there was no significant difference on the items in the questionnaire related to the perception of safety in the culinary laboratory. Based on the analysis of questionnaires, indicating the students' perception of safety practices are able to make a positive contribution to the lives of over a survey done by Rahman \& Hamid (2011) and Yusuf (2014) that the perception of the practice in the context of safety in a culinary laboratory, knowledge, and attitudes held by students must be accompanied by the adoption of positive science and ethics. Therefore, it is clear that a positive perception or the implementation of safe work, to some extent, raises a good boost for the students to do better and excel in his field of work.

Ahmad (2015) states that students who have a positive perception of themselves, they will influence the performance of his colleagues in which they will give a positive outlook which can reflect a better effect in the atmosphere of safety practices in culinary laboratory and if the perception of the situation otherwise it can give a negative impact on safety practices in the culinary laboratory which resulted in an accident will occur during practical work undertaken. The findings also showed that the process of practical works in a more orderly implementation of the work in the culinary laboratory is also able to build a good perception of safety practices through the adoption of a person. Sharudin \& Yahaya (2008) explain that laboratory management and working properly and regularly is not only beneficial to the process of teaching and learning, but it is the pride of the individuals.
Bakar (2012) and Yusuf (2014) claimed that safety practices can foster the students to make safety as a priority in the laboratory and practical works smoothly but it can also be forwarded to the working environment.

In addition, a good attitude and ethical behavior in the performance of work in the culinary laboratory is able to build a good perception of safety practices by adopting safety rules (Hargiyanto, 2011; Putri \& Hidayat, 2017). These findings are consistent with Saher (2015), Mukhari \& Johari (2010) and Sharudin \& Yahaya (2008) who said that regulatory practice in the laboratory is the responsibility of everyone who is in the laboratory. In compliance with the regulations in the culinary laboratory, all the risks associated with accidents can be avoided. This is because the main cause of accidents is the attitude and negligence of a person. According to Yusof (2014), the accident occurred is due to the careless attitude in maintaining the safety of themselves and others. Partners are a shared responsibility because the friend is the one who was within the culinary laboratory. Therefore, we can see the experience of safety practices that students acquire the practical work or working in the industry can establish a positive perception to students in improving their work processes in the life of the future and can continue up to the working environment and can create a process that is safe, especially the culinary laboratory.

This study also demonstrated the level of knowledge and mastery of students' knowledge of safety practices in the culinary laboratory during the practical work is carried out. After the analysis, the science that deals with the use and storage equipment properly is one of the important knowledge to ensure that equipment is not damaged. It shows that the user should know the safety regulations in the use of equipment before using it. This is consistent with Said \& Zahari (2011) and Yusof (2014) who said that before using the equipment in the laboratory, students should know how to use the 
equipment and how to operate it properly. This is because it will cause problems if the use is not used properly.

According to Said \& Noor (2010) and Saher (2015), the equipment should be stored properly to avoid accidents and also should be cleaned to avoid other problems arise later. In addition, analysis of the findings also shows that students' knowledge in laboratory management in terms of lighting, hygiene, and safety in the culinary laboratory. The results showed that the students have basic knowledge about the use of lighting in the culinary laboratory for their safety when doing something in the laboratory. Based on Royo \& Mahmood (2011), teaching and learning in the culinary laboratory, lighting plays an important role to smooth out practical work in the laboratory. Besides, Said \& Zahari (2011) and Saher (2015) claimed the needs of a lighting system, air distribution, and temperature as well as to avoid disturbing the comfort of all students in the culinary laboratory.

The findings showed the students' knowledge of safety before entering the culinary laboratory is important. Before entering the culinary laboratory, students should have the knowledge of safety in the culinary laboratory adequately (Saher, 2015). Ishak (2013),Yusof (2014) and Mukhari \& Johari (2010) stated that knowledge of personal safety which includes the use of personal jewelry is prohibited while in the culinary laboratory to avoid harm to the individual. Therefore, personal safety in the culinary laboratory is important and should be practiced to continue into the nature of work to ensure the safety and secure (Hidayat \& Wahyuni, 2016). Moreover, the basic knowledge is related to the lecturer instructions' before starting the practical work which is important for a student to ensure the safety practices being practiced and secure from harm (Ishak, 2013; Yusof, 2014). More knowledge and experience are important for students to realize the practice and complying in the culinary laboratory to prevent an accident while doing practical work in the culinary laboratory (Mukhari \& Johari, 2010; Ishak, 2013; Yusof, 2014).

Attitude plays an important role in avoiding themselves from any danger in the culinary laboratory. According to Selamat et al. (2010), the attitude of students who are concerned about safety practices and be conscious of the task or job can reduce the danger to themselves and their peers. Therefore, they can establish a positive working culture and attitude are always concerned about the safety in the culinary laboratory. Students who have a sense of responsibility to be more proactive in its activities as complying with the culinary laboratory that had been set (Royo \& Mahmood, 2011; Andin et al., 2010). Thus, a positive attitude in all aspects of spiritual and physical practices are capable of salvation regardless of time and place.

Safety practice in the culinary laboratory is in a safe and comfortable when students constantly practice good habits and positive (Ishak, 2013; Saher, 2015). From the analysis of the study, it can be seen good working culture attitude that can create a safe and orderly manner in which students are disciplined to clean equipment and make sure the equipment is in good condition before and after use (Mukhari \& Johari, 2010). This is in line with the study of Ishak (2013) and Said \& Zahari (2011), which is students should know the procedures and rules on using the equipment to be cautious in handling and care of the equipment so that the equipment is not easily damaged. Therefore, the attitude of disciplined students in care such as cleaning and repair equipment after use can establish a good safety practice.

In addition, the student's responsible attitude will propel a student to comply with the rules and practice safe working culture. Based on Andin, Abdullah \& Hassan (2010) and Royo \& Mahmood (2011), students who have a responsibility will comply with safety regulations in the laboratory and will seek permission from the lecturer in the use of equipment to protect goods in the culinary 
laboratory and can avoid accidents and damage to equipment. Therefore, the safety-conscious attitude in the culinary laboratory encourages the students to always remember the dangers so that they do not do negative attitudes in the culinary laboratory so that accidents can be reduced.

\section{CONCLUSION}

Finally, the results showed that the perceptions, and attitudes towards safety in culinary laboratory practices at Muar Vocational Colleges are at a high level. Indirectly, student personality can be formed. In addition, the findings demonstrate that a culture that is safe and orderly able to create a disciplined and responsible attitude. However, there are a few students who still ignore safety practices. This is caused by the students who are less exposed to the lack of safety in the culinary laboratory and in the knowledge of safety at the culinary laboratory.

\section{REFERENCES}

Ahmad, K. 2015. Pengaruh Persepsi Siswa tentang Metode Mengajar Guru, Fasilitas Belajar, dan Motivasi Belajar terhadap Prestasi Belajar Siswa Kompetensi Keahlian Teknik Audio Video di SMK N 3 Yogyakarta (Doctoral dissertation, UNY).

Alavi, K., \& Sail, R. M. 2015. Tahap Penerimaan Masyarakat terhadap Latihan Kemahiran di Malaysia. (The Level of Public Acceptance of Skills Training in Malaysia) Sains Sosial dan kemanusian, e-Bangi. 10.1, 16

Andin, C., Abdullah, N. Q., \& Hassan, I. H. . 2010. Pengetahuan dan Sikap Pelajar Pkpg dan Perdana Tahun Empat Sarjana Muda Teknologi serta Pendidikan (Kemahiran Hidup) terhadap Amalan dan Peraturan Keselamatan di Bengkel Fabrikasi Logam dan Kimpalan, N30, Universiti Teknologi Malaysia: Satu Tinjauan
Aziz, A. A., Baruji, M. E., Abdullah, M. S., Him, N. F. N., \& Yusof, N. M. 2015. An Initial Study on Accident Rate in the Workplace through Occupational Safety and Health Management in Sewerage Services. International Journal of Business and Social Science. 6.2

Bahari, I. 2006. Pengurusan Keselamatan dan Kesihatan Pekerjaan,Mc Graw-Hill (Malaysia)

Bakar, N. A. 2012. Penguasaan Amalan Keselamatan Bengkel di Kalangan Pelajar Kursus Elektrik di Salah Sebuah Kolej Komuniti di Negeri Selangor (Doctoral Dissertation, Universiti Teknologi Malaysia)

Bakar, Z. B. A., \& Zulpakar, K. A. B. M. 2008. Amalan Keselamatan Bengkel di Kalangan Pelajar-Pelajar Tingkatan 3 Aliran Kemahiran Hidup Semasa Melakukan Kerja-Kerja Amali di Sekolah Menengah Kebangsaan Taman Universiti, Johor. Universiti Teknologi Malaysia

Boon, Y., \& Kamarudin, S. 2010. Tahap Penguasaan Amalan Keselamatan Bengkel Kemahiran Hidup dalam Kalangan Pelajar Tingkatan Empat di Sekolah Menengah Kebangsaan Dato Yunus Sulaiman, Pekan Nanas, Pontian, Johor Darul Takzim

Che Juhan Negara, R. 2012. Tahap Kesediaan Pelajar Kejuruteraan Politeknik Terhadap Keselamatan di Dalam Bengkel (Doctoral dissertation, Universiti Tun Hussein Onn Malaysia)

Cullen, F. 2010. Phenomenological views and analysis of culinary arts student attitudes to national and international internships: the "nature of being" before, during, and after the international internship. Journal of Culinary Science \& Technology. 8.2-3, $87-105$

Flin, R. H., O'Connor, P., \& Crichton, M. 2008. Safety At the Sharp End: A Guide To Non-Technical Skills. Ashgate Publishing 
Ghafar, M. N. 2003. Reka bentuk tinjauan soal selidik pendidikan. Fakulti Pendidikan, Universiti Teknologi Malaysia.

Hargiyanto, P. 2011. Analisis Kondisi dan Pengendalian Bahaya di Bengkel/ Laboratorium Sekolah Menengah Kejuruan. Jurnal Pendidikan Teknologi dan Kejuruan. 20.2

Hidayat, N., \& Wahyuni, I. 2016. Kajian Keselamatan dan Kesehatan Kerja Bengkel di Jurusan Pendidikan Teknik Sipil dan Perencanaan Fakultas Teknik UNY. Jurnal Pendidikan Teknologi dan Kejuruan. 23.1, 51-66

Ishak, S. H. 2013. Tinjauan terhadap amalan keselamatan dalam kalangan pelajar dan pensyarah di Makmal Kejuruteraan Universiti Tun Hussein Onn Malaysia (Doctoral dissertation, Universiti Tun Hussein Onn Malaysia)

Ismail, S., \& Talip, F. A. . 2010. Kepuasan Bekerja Staf Akademik Jabatan Pendidikan Teknikal dan Kejuruteraan, Fakulti Pendidikan. Universiti Teknologi Malaysia, Skudai. Jabatan Pendidikan Teknikal dan Kejuruteraan, Fakulti Pendidikan. Universiti Teknologi Malaysia.Skudai, 1-7

Jaafar, M. H., Arifin, K., Aiyub, K., Razman, M. R., \& Ahmad, M. . 2015. A Review of Occupational Safety and Health(OSH) Accidents and Contributing Factors In Construction Industry. Journal of Food, Agriculture, and Environment. 132, 238244

Jalil, N. 2014. Kecenderungan Pelajar Cemerlang Akademik terhadap Pemilihan Bidang PTV (Doctoral Dissertation, Universiti Tun Hussein Onn Malaysia)

Department of Occupational Safety and Health 2016. Kemalangan di Sektor Perindustrian. Jabatan Keselamatan dan Kesihatan Pekerjaan. Kementerian Sumber Manusia, Malaysia
Konting, M. 2009. Kaedah penyelidikan pendidikan. Kuala lumpur: Dewan bahasa dan pustaka

Malamud, O., \& Pop-Eleches, C. 2010. General Education Versus Vocational Training: Evidence From An Economy In Transition. The Review Of Economics and Statistics.92.1, 43-60

Mansor Wan Mahmood, W., \& Zakaria, R. . 2007. Profitability and capital structure of the property and construction sectors in Malaysia. Pacific Rim Property Research Journal. 13. 1, 92-105

Mills Jr, R. J., Eschenfelder, M., \& Rudd, D. P. 2009. Curriculum Analysis and Development for Advanced Foods and Catering Operations: A Study of Facilities and Resources in an Undergraduate Hospitality Class. Research in Higher Education Journal. 2.1

Mohd Yusoff, N., Osman, R., Shaari, A. S., \& Ghazali, M. I. 2012. Kemahiran Belajar dalam Kalangan Pelajar Bidang Pendidikan. Seminar Kebangsaan Majlis Dekan Pendidikan IPTA 2012, 1-12

Mukhari, A. W., \& Johari, S. 2010. Persepsi Pelajar terhadap Penguasaan Pengetahuan Dan Ketrampilan Berkaitan Duty 1: Adhere to Safety Rules and Regulation di Kalangan Pelajar Tahap 3 di Salah Sebuah IKBN di Johor

Ozilgen, S. 2011. Food safety education makes the difference: food safety perceptions, knowledge, attitudes and practices among Turkish university students. Journal für Verbraucherschutz und Lebensmittel sicherheit.6.1, 25-34

Piaw, C. Y. 2014. Kaedah Penyelidikan. Selangor: Edisi Ketiga

Putri, K., \& Nur Hidayat, S. P. 2017. Penerapan Keselamatan dan Kesehatan Kerja (K3) pada Praktik Kerja Kayu Siswa Kelas XII Program Keahlian Teknik Gambar Bangunan SMK Negeri 2 Depok Sleman 
Yogyakarta. E-Journal Pend. Teknik Sipil Dan Perencanaan. 5.4, 7

Rahman, M.A.A., \& Hamid, I.A. 2011. Pengetahuan dan Pengamalan Keselamatan Bengkel di Kalangan Para Pelajar Kursus Penyenggaraan Bangunan di Sebuah Kolej Komuniti

Royo, M.A., \& Mahmood, H. 2011. Faktorfaktor kelemahan yang mempengaruhi pencapaian cemerlang dalam mata pelajaran Reka Cipta. Journal of Education Psychology and Counseling, $2,145-174$

Saher, M.N. 2015. Amalan Pengurusan Keselamatan Bengkel Kemahiran Hidup (KHB) Sekolah Menengah Harian Daerah Batu Pahat (Doctoral dissertation, Universiti Tun Hussein Onn Malaysia)

Said, M.M., \& Zahari, R. 2011. Kajian Aplikasi Ergonomik Terhadap Pelajar Ketika Melakukan Kerja-Kerja Amali Bengkel Di Kalangan pelajar-Pelajar $4 \mathrm{SPH}$ PKPG Fakulti Pendidikan UTM. Journal of Technical, Vocational \& Engineering Educational. 3, 116-131

Said, M.R.M., \& Noor, N.A.M. 2010. Amalan Kebersihan Makanan dalam Kalangan Pengendali-Pengendali Kantin di Sekolah Zon Skudai
Selamat, K., Minghat, A. D., \& Buhari, N. 2010. Tahap Kesediaan Pelajar-Pelajar Kursus Binaan Bangunan Terhadap Keselamatan di Dalam Bengkel: Satu Tinjauan di Tiga Buah Sekolah Menengah Teknik di Negeri Johor

Sharudin, S. A., \& Yahaya, A. 2008. Faktor yang Mempengaruhi Keberkesanan Pengajaran dan Pembelajaran di dalam Bengkel Vokasional di Dua Buah Sekolah Menengah Teknik di Negeri Sembilan (Doctoral dissertation, Universiti Teknologi Malaysia

Tran, L. T., \& Nyland, C. 2013. Competencybased training, global skills mobility and the teaching of international students in vocational education and training. Vocational Education \& Training. 65.1, $143-157$

Winberg, T. M., \& Berg, C. A. R. . 2007. Students' Cognitive Focus During a Chemistry Laboratory Exercise: Effect Of a Computer-Simulated prelab. Journal of Reseach In Science Teaching. 44.8, 1108-1133

Yusof, M. K. 2014. Amalan Keselamatan Bengkel Dalam Kalangan Pelajar Kolej Vokasional Temerloh. (Doctoral dissertation, Universiti Tun Hussein Onn Malaysia) 